\title{
Antimony in soils of SW Poland-an overview of potentially enriched sites
}

\author{
Karolina Lewińska (iD) Anna Karczewska
}

Received: 23 October 2018 / Accepted: 4 January 2019/Published online: 15 January 2019

(C) The Author(s) 2019

\begin{abstract}
Great concern has been recently focused on antimony in the environment due to the potential risks posed by this metalloid to humans. In Poland, the concentrations of $\mathrm{Sb}$ in soils have not been well recognized. The aim of this study was to identify the sites in southwestern Poland where soils are considerably enriched in $\mathrm{Sb}$ and to make a rough assessment of a related environmental risk. One hundred forty-four samples were collected from 20 Lower Silesian locations chosen as potentially enriched in $\mathrm{Sb}$ that included historical mining sites, tailings impoundments, close vicinities of operating copper smelters, and landfills as well as currently operating and historical shooting ranges. Total concentrations of $\mathrm{Sb}$ in soils were determined, and related pollution indices were calculated. Several locations were found where soils contain high concentrations of $\mathrm{Sb}$, with a maximum that exceeded $5600 \mathrm{mg} \mathrm{kg}^{-1} \mathrm{Sb}$ in the alluvial soil affected by historical mining. Sequential extraction showed a considerably high percentage of $\mathrm{Sb}$ extracted in potentially soluble fractions 1 (nonspecifically sorbed) and 2 (specifically sorbed), particularly in the samples collected from shooting ranges and
\end{abstract}

K. Lewińska $(\bowtie)$

Department of Soil Science and Remote Sensing of Soils, Adam Mickiewicz University in Poznań, ul. Krygowskiego 10, 61-680 Poznań, Poland

e-mail: karolina.lewinska@amu.edu.pl

A. Karczewska

Institute of Soil Science and Environmental Protection, Wrocław University of Environmental and Life Sciences, ul. Grunwaldzka 53, 50-357 Wrocław, Poland in some samples from historical mine areas. This result provides a strong premise for further risk- and remediation-oriented examination of soils in those sites. More detailed research is needed to determine a spatial extent of soil contamination in the sites identified as highly enriched in Sb. Contrary to these findings, soil material collected from copper tailings impoundments, surroundings of smelters, and landfills did not show any particular enrichment in $\mathrm{Sb}$.

Keywords Antimony · Mining · Shooting range · Soil · Speciation $\cdot$ Geoaccumulation index

\section{Introduction}

Concentrations of $\mathrm{Sb}$ in Polish soils have not been well recognized, and the only data available are those collected from the national monitoring of arable soils and grasslands, which revealed the $\mathrm{Sb}$ content in soils in the range 0.06-1.03 $\mathrm{mg} \mathrm{kg}^{-1}$ (Pasieczna 2012). These data, compared with $\mathrm{Sb}$ concentrations in European topsoils, reported by Salminen et al. (2005), that range from 0.02 to $31.1 \mathrm{mg} \mathrm{kg}^{-1}$, and with the data provided by KabataPendias (2011) for unpolluted soils $0.25-1.04 \mathrm{mg} \mathrm{kg}^{-1}$, indicate clearly that the Polish survey did not identify any soils highly enriched in Sb. However, we supposed that local cases of soil contamination with $\mathrm{Sb}$ are quite likely, particularly in the areas of present or historical $\mathrm{Sb}$ mining and processing. Such cases of soil enrichment in $\mathrm{Sb}$ were reported from various sites in the world that involved both historical and currently operating mines 
and smelters. Additionally, coal combustion, wastes dumps, power plants, battery factories, production and use of bullets, flame retardants and PETs, and automotive production can act as considerable sources of $\mathrm{Sb}$ in the environment (Filella et al. 2002; Reimann et al. 2010; Wilson et al. 2010; Lewińska et al. 2017; Földi et al. 2018; Li et al. 2018). A brief review of related bibliography indicates that mining and ore processing are the main sources of local soil enrichment in Sb. For instance, in the areas of mining activity in China (region Xikuangshan in Hunan), the content of $\mathrm{Sb}$ in soils reached $5045 \mathrm{mg} \mathrm{kg}^{-1}$ (He 2007) and the concentrations of $\mathrm{Sb}$ in waste material were even higher, i.e., $11,798 \mathrm{mg} \mathrm{kg}^{-1}$. Similar concentrations of $\mathrm{Sb}$, up to $11,560 \mathrm{mg} \mathrm{kg}^{-1}$, were found in mine tailings in the French Massif Central (Courtin-Nomade et al. 2012). Very high concentrations of $\mathrm{Sb}$ in soils, over $9000 \mathrm{mg} \mathrm{kg}^{-1}$, were also reported from mine sites in Dúbrava, Slovakia (Hiller et al. 2012), and the data up to $4400 \mathrm{mg} \mathrm{kg}^{-1} \mathrm{Sb}$ were recorded from Su Suergiu in Sardinia, Italy (Cidu et al. 2014). Macgregor et al. (2015) identified the sites with soil Sb concentrations up to $222 \mathrm{mg} \mathrm{kg}^{-1}$ in the surroundings of Glendinning mine (Scotland). Smelting activity can also cause soil contamination with $\mathrm{Sb}$. Wilson et al. (2004) reported as high value of $\mathrm{Sb}$ concentration in soil as $80,200 \mathrm{mg} \mathrm{kg}^{-1}$ in the close neighborhood of a smelter in New Zealand. Another kind of industrial activities that can considerably enrich soils in $\mathrm{Sb}$ is battery factories. The concentrations of Sb up to $112 \mathrm{mg} \mathrm{kg}^{-1}$ were recorded from the surrounding of $\mathrm{Pb}-\mathrm{Sb}$ recycling factory in Spain (Mykolenko et al. 2018). As antimony is widely used in the production of bullets that usually contain $2-5 \%$ of Sb (Johnson et al. 2005; Laporte-Saumure et al. 2011), shooting range soils are typically the sites reported as highly contaminated with $\mathrm{Sb}$. In an Australian study, the concentrations of $\mathrm{Sb}$ in such soils reached $252 \mathrm{mg} \mathrm{kg}^{-1}$ (Sanderson et al. 2012), and the maximum soil concentration reported from the German Army shooting ranges was $437 \mathrm{mg} \mathrm{kg}^{-1} \mathrm{Sb}$ (Spuller et al. 2007). A shooting range in Lucerna (Switzerland) was reported to contain extremely high concentration of Sb, i.e., $8230 \mathrm{mg} \mathrm{kg}^{-1}$ (Robinson et al. 2008), while considerably lower data were recorded from Norway, with the maximum value of $12 \mathrm{mg} \mathrm{kg}^{-1} \mathrm{Sb}$ (Okkenhaug et al. 2016). Literature reported also high concentrations of $\mathrm{Sb}$ in soils in the neighborhoods of landfills and waste incinerators (Filella et al. 2009; Kabata-Pendias 2011). Hu et al. (2015) found $9000 \mathrm{mg} \mathrm{kg}^{-1} \mathrm{Sb}$ in the top soils of brake pad dumpsite located in Miyun County in China. Okkenhaug et al. (2015) stressed that very high Sb concentrations can be present in waste electrical and electronic equipment, in vehicle plastic (1238$1715 \mathrm{mg} \mathrm{kg}^{-1}$ ), and in vehicle fluff (34$4565 \mathrm{mg} \mathrm{kg}^{-1}$ ). Although the latter data refer to solid wastes, and not to soils, high potential risk posed on the environment by the wastes rich in $\mathrm{Sb}$ disposed in the landfills cannot be ignored. Moreover, it was proven that the leachates from municipal solid wastes can contain high concentrations of Sb, up to $3.19 \mathrm{mg} \mathrm{L}^{-1} \mathrm{Sb}$ (ElFadel et al. 2002), that can easily move into soils and groundwater.

As pointed out above, the knowledge about Sb content in Polish soils is very limited. If considering the fact that $\mathrm{Sb}$-rich ores were mined in the past in several sites of the Sudetenland, local enrichment of the environment in $\mathrm{Sb}$ can there be expected. Our preliminary study (Lewińska et al. 2017), carried out in the surroundings of the only historical stibnite (antimonite) mine in the Polish part of the Sudetes (Maczka and Stysz 2008), confirmed that mine dump material and soils there contain up to $427 \mathrm{mg} \mathrm{kg}^{-1} \mathrm{Sb}$. Elevated concentrations of $\mathrm{Sb}$ in soils should also be expected in the sites of former arsenic and polymetallic ore mining and processing, such as Złoty Stok, Czarnów, and Radzimowice (Karczewska et al. 2007, 2013; Krysiak and Karczewska 2007; Kabała 2015), as Sb occurs in those ores as an accompanying element (Mikulski 2010; Wilson et al. 2013; Macgregor et al. 2015). The soils of two Lower Silesian shooting ranges, in Wrocław and Oleśnica, turned out to contain enhanced concentrations of $\mathrm{Sb}$, as it was revealed in our introductory study (Lewińska et al. 2017). The main aim of the present work was to deliver a possibly comprehensive picture of soil enrichment in Sb in Lower Silesia (SW Poland). It is worth mentioning that Polish law does not regulate the permissible concentrations of $\mathrm{Sb}$ in soils. Similarly, in most countries, $\mathrm{Sb}$ is absent in soil quality standards. However, the Geological Survey of Norway proposed a value $40 \mathrm{mg} \mathrm{kg}^{-1}$ as a permissible content of $\mathrm{Sb}$ in soils (Okkenhaug et al. 2016), and the Dutch soil standards accept the level of $100 \mathrm{mg} \mathrm{kg}^{-1}$ (van Leeuwen and Aldenberg 2012). Chang et al. (2002), the authors of a report for WHO, recommended the value $36 \mathrm{mg} \mathrm{kg}^{-1}$ as a maximum level of $\mathrm{Sb}$ in soils that can be fertilized with sewage sludge.

Various indices have been invented in order to classify the data on soil enrichment with potentially toxic 
elements, such as $\mathrm{Sb}$. An enrichment factor (EF), proposed by Sutherland (2000), can be applied to assess the degree of pollution and the impact of anthropogenic activity onto soils (Kowalska et al. 2016; El-Badry and Khalifa 2017). EF is based on standardization of a tested element in relation to the reference one (Loska et al. 2004) and can be calculated according to the Formula (1). Sutherland (2000) proposed, accordingly, a fivecategory system for the assessment of soil pollution (Table 1).

$$
E F=\frac{\frac{\text { Cn }(\text { sample })}{\text { Cref }(\text { sample })}}{\frac{\text { GBn }}{\text { GBref }}}
$$

where

$\mathrm{Cn}$ the content of a given element in the

(sample) environment examined, e.g., in soil

Cref the content of a reference element, e.g., Fe/

$\mathrm{Al} / \mathrm{Ca} / \mathrm{Ti} / \mathrm{Sc} / \mathrm{Mn}$, in the examined environment

GBn the content of examined element in the reference environment

GBref the content of the reference element, e.g., $\mathrm{Fe} / \mathrm{Al} / \mathrm{Ca} / \mathrm{Ti} / \mathrm{Sc} / \mathrm{Mn}$, in the reference environment

Another index, proposed originally as a quantitative measure of pollution in aquatic sediments (Müller 1986), and adopted to soils, is an index of geoaccumulation $\left(I_{\mathrm{geo}}\right)$. It is based on the comparison of current concentrations of an element in soil or

Table 1 Assessment of soil pollution based on the EF values (Sutherland 2000)

\begin{tabular}{ll}
\hline Value & Soil contamination category \\
\hline $\mathrm{EF}<2$ & $\begin{array}{c}\text { Depletion to minimal enrichment suggestive of no } \\
\text { or minimal pollution } \\
2<\mathrm{EF}<5\end{array}$ \\
$\begin{array}{c}\text { Moderate enrichment, suggestive of moderate } \\
\text { pollution }\end{array}$ \\
$5<\mathrm{EF}<20$ & $\begin{array}{c}\text { Significant enrichment, suggestive of significant } \\
\text { pollution signal }\end{array}$ \\
$20<\mathrm{EF}<40$ & $\begin{array}{c}\text { Very highly enriched, indicating a very strong } \\
\text { pollution signal }\end{array}$ \\
$\mathrm{EF}>40$ & $\begin{array}{c}\text { Extremely enriched, indicating an extreme } \\
\text { pollution signal }\end{array}$ \\
\hline
\end{tabular}

sediment and its geochemical background, calculated according to the following Formula (2):

$I_{\text {geo }}=\log _{2} \frac{\mathrm{Cn}}{1.5 \times \mathrm{GB}}$

where

Cn concentration of metal (or metalloid) in the sediment or soil

GB value of geochemical background related to local geological conditions

1.5 constant that allows to analyze natural variability of element in the environment

Accordingly, six classes of $I_{\text {geo }}$ have been distinguished that define various levels of pollution (Table 2).

These two pollution indices can be used as useful tools to assess a potential environmental risk (Wang et al. 2018). It should be stressed, however, that they are both based on the total concentrations of toxic elements and do not take into account their mobility or solubility. On the other hand, however, it is obvious that the adverse effects posed on the environment by the presence of such elements depend not only on their total concentrations, but also on their speciation that determines a real and potential lability and bioavailability. The knowledge on speciation of potentially toxic elements is therefore of crucial importance from the standpoint of environmental risk. The methods commonly applied to determine operationally defined species of elements in soils are sequential extractions. They are believed to distinguish between the forms of elements that can be released from soil solid phase in various conditions. From among numerous procedures, the one optimized by Wenzel

Table 2 The classes of soil quality based on $I_{\text {geo }}$ values (Müller 1986; Loska et al. 2004; El-Badry and Khalifa 2017; Kowalska et al. 2018)

\begin{tabular}{lll}
\hline Class & Value & Soil quality \\
\hline 0 & $I_{\text {geo }} \leq 0$ & Practically unpolluted \\
1 & $0<I_{\text {geo }}<1$ & Unpolluted to moderately polluted \\
2 & $1<I_{\text {geo }}<2$ & Moderately polluted \\
3 & $2<I_{\text {geo }}<3$ & Moderately to strongly polluted \\
4 & $3<I_{\text {geo }}<4$ & Strongly polluted \\
5 & $4<I_{\text {geo }}<5$ & Strongly to very strongly polluted \\
6 & $5<I_{\text {geo }}$ & Very strongly polluted \\
\hline
\end{tabular}


et al. (2001) was designed particularly for As, an element that behaves in soils similarly to $\mathrm{Sb}$, and therefore, it is also the most appropriate for determination of operationally defined $\mathrm{Sb}$ species in soils (Müller et al. 2007; Ettler et al. 2010; Wilson et al. 2010; Fu et al. 2016; Okkenhaug et al. 2016). The procedure takes into account the anionic nature of metalloids and extracts their five fractions: (1) non-specifically sorbed, which can be considered "easily soluble"; (2) specifically sorbed; (3) associated with amorphous and poorly crystalline hydrous oxides of $\mathrm{Fe}$ and $\mathrm{Al}$; (4) associated with well-crystallized hydrous oxides of $\mathrm{Fe}$ and $\mathrm{Al}$; and (5) residual phases (Table 3 ).

The knowledge on speciation of a pollutant in soil is crucial for both assessment of environmental risk and planning a proper remediation strategy. Two opposite strategies of remediation may be applied to soils polluted with $\mathrm{Sb}$ : either its immobilization or decontamination. The latter approach may in some cases turn out unfeasible and may cause temporarily detrimental effects to soil biota. Moreover, the technologies of soil decontamination are very expensive. On the contrary, the techniques of immobilization are widely used because of their low costs, low risk of side effects, and social acceptance (Lewińska et al. 2018). Different kinds of amendments can be used for immobilization of $\mathrm{Sb}$ in soils, including organic compounds; oxides and hydroxides of $\mathrm{Fe}, \mathrm{Mn}$, and As; and different kinds of waste rich in those components (Leuz et al. 2006; Steely et al. 2007; Okkenhaug et al. 2016). However, in the areas contaminated by various metals and metalloids, immobilization can be challenging due to the differences in their mobility with changing $\mathrm{pH}$ (Barker et al. 2019; Okkenhaug et al. 2011, 2016).

The aim of this study was to recognize the sites in south-western Poland where soils are considerably enriched in Sb. For those sites, the pollution indices were calculated in order to roughly assess related contamination classes. In the cases of particularly high enrichment, potential solubility of Sb in soils was determined based on sequential extraction as an introductory step for the assessment of environmental risk.

\section{Materials and methods}

Soil material

One hundred forty-four samples were collected from 20 locations (Fig. 1) in Lower Silesia, the south-western part of Poland, chosen as potentially enriched in $\mathrm{Sb}$. They represented the surroundings of historical mining sites situated in various regions of Central Sudetes: a stibnite mine (Dębowina), arsenic mines (Czarnów, Złoty Stok) and polymetallic ore mines (Bardo, Bystrzyca Górna, Dziećmorowice, Modliszów, Radzimowice, Rościszów, Srebrna Góra) (Karczewska et al. 2007; Stysz et al. 2012; Mączka and Stysz 2013; Nejbert et al. 2013; Zagożdżon and Madziarz 2015; Lewińska et al. 2017), close vicinities of operating copper smelters in Głogów and Legnica (Karczewska 1996; Szerszeń et al. 1993), tailings impoundments Żelazny Most and Wartowice working for copper industry (Karczewska et al. 2017), currently operating and historical shooting ranges situated in Wrocław and Oleśnica (Lewińska et al. 2017), two closed municipal landfills in Wrocław, and a waste dumping site in Nowa Wieś Legnicka (Table 4). The landfill Ziębicka in Wrocław used, additionally, to serve as a dumping site for railway and gasworks, the operators that produced wastes rich in scrap-metal. The soil samples were basically collected from a surface soil layer $(0-10 \mathrm{~cm})$ and occasionally

Table 3 Procedure of sequential extraction based on Wenzel et al. (2001)

\begin{tabular}{|c|c|c|c|c|}
\hline Fraction & Extractant & Extraction conditions & $\mathrm{SSR}^{*}$ & Wash step \\
\hline 1 & $\left(\mathrm{NH}_{4}\right)_{2} \mathrm{SO}_{4}(0.05 \mathrm{M})$ & $4 \mathrm{~h}$ shaking, $20^{\circ} \mathrm{C}$ & $1: 25$ & - \\
\hline 2 & $\left(\mathrm{NH}_{4}\right) \mathrm{H}_{2} \mathrm{PO}_{4}(0.05 \mathrm{M})$ & $16 \mathrm{~h}$ shaking, $20{ }^{\circ} \mathrm{C}$ & $1: 25$ & - \\
\hline 3 & $\mathrm{NH}_{4}$-oxalate buffer $(0.2 \mathrm{M})$; pH 3.25 & $4 \mathrm{~h}$ shaking in the dark, $20^{\circ} \mathrm{C}$ & $1: 25$ & $\begin{array}{l}\mathrm{NH}_{4} \text {-oxalate }(0.2 \mathrm{M}) \text {; pH } 3.25 \mathrm{SSR} 1: 12.5 \text {; } \\
10 \text { min shaking in the dark }\end{array}$ \\
\hline 4 & $\begin{array}{l}\mathrm{NH}_{4} \text {-oxalate buffer }(0.2 \mathrm{M}) ;+ \text { ascorbic } \\
\quad \text { acid }(0.1 \mathrm{M}) \text { pH } 3.25\end{array}$ & $\begin{array}{l}30 \mathrm{~min} \text { in a water basin at } \\
96 \pm 3^{\circ} \mathrm{C} \text { in the light }\end{array}$ & $1: 25$ & $\begin{array}{l}\mathrm{NH}_{4} \text {-oxalate }(0.2 \mathrm{M}) \text {; pH } 3.25 \mathrm{SSR} 1: 12.5 \text {; } \\
10 \text { min shaking in the dark }\end{array}$ \\
\hline 5 & $\mathrm{HCl}: \mathrm{HNO}_{3}(3: 1)$ & Microwave digestion & $1: 50$ & \\
\hline
\end{tabular}

*SSR soil to solution ratio 


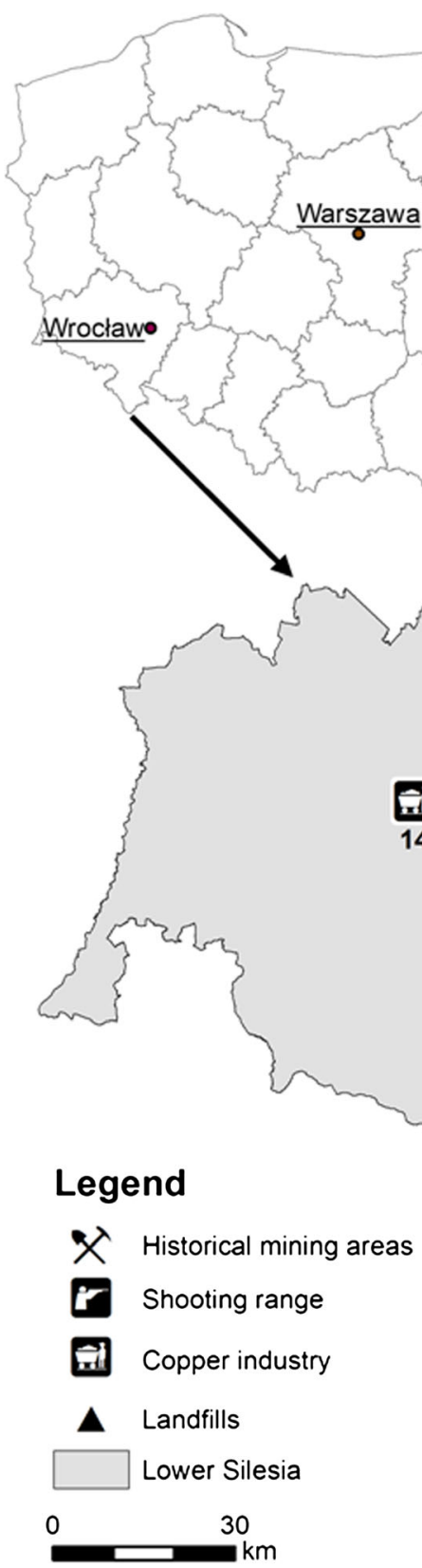

Fig. 1 Location of sampling sites. Historical mining areas: 1. Bardo, 2. Bystrzyca Górna, 3. Czarnów, 4. Dębowina, 5. Dziećmorowice, 6. Modliszów, 7. Radzimowice, 8. Rościszów, 9. Srebrna Góra, 10. Złoty Stok, 11. Złoty Stok valley. Copper

also from the subsurface layer $(10-25 \mathrm{~cm})$. The stones and coarse gravel particles $(>5 \mathrm{~mm})$ were sieved out on site. Their approximate percentage was determined in the field.

Air-dried soil samples were crushed and passed through a 2-mm stainless steel sieve. Basic soil properties were examined. Soil grain size distribution was determined using the hydrometer method (Gee and Bauder 1986), and the textural groups were assigned according to USDA classification (Soil Survey Staff 1999). The content of organic carbon (SOC) in soils was measured after sulfochromic oxidation on a tube 
Table 4 Description of sampling sites with their current type of use

\begin{tabular}{|c|c|c|c|c|c|c|}
\hline Location & Sampling site & $\begin{array}{l}\text { Geographical } \\
\text { region }\end{array}$ & $\begin{array}{l}\text { Depth } \\
(\mathrm{cm})\end{array}$ & $\begin{array}{l}\text { Number } \\
\text { of } \\
\text { samples }\end{array}$ & Type of use & Additional information \\
\hline \multirow{16}{*}{$\begin{array}{l}\text { Historical } \\
\text { mining } \\
\text { areas }\end{array}$} & Bardo & Bardzkie Mts. & $0-10$ & 3 & Dump & Very coarse and gravel \\
\hline & Bystrzyca Górna & Sowie Mts. & $0-10$ & 6 & Forest/dump & $\begin{array}{l}\text { Coarse; up to } 6070 \mathrm{mg} \mathrm{kg}^{-1} \mathrm{~Pb} \text {, } \\
\quad 6840 \mathrm{mg} \mathrm{kg}^{-1} \mathrm{Zn}\end{array}$ \\
\hline & \multirow[t]{4}{*}{ Czarnów } & \multirow{4}{*}{$\begin{array}{l}\text { Rudawy } \\
\text { Janowickie } \\
\text { Mts. }\end{array}$} & $0-10$ & 4 & Slag dump & \multirow{4}{*}{$\begin{array}{l}\text { Very coarse and gravel; up to } \\
\quad 49,900 \mathrm{mg} \mathrm{kg}^{-1} \mathrm{As}\end{array}$} \\
\hline & & & $0-10$ & 7 & Forest/dump & \\
\hline & & & $0-10$ & 4 & Grassland & \\
\hline & & & $10-25$ & 3 & Grassland & \\
\hline & Dębowina & Bardzkie Mts. & $\begin{array}{l}0-10 \\
10-25\end{array}$ & $\begin{array}{r}10 \\
2\end{array}$ & Forest/dump & Up to $2797 \mathrm{mg} \mathrm{kg}^{-1} \mathrm{As}$ \\
\hline & Dziećmorowice & Sowie Mts. & $0-10$ & 4 & Woodland/dump & Up to $8899 \mathrm{mg} \mathrm{kg}^{-1} \mathrm{Ba}$ \\
\hline & Modliszów & Sowie Mts. & $0-10$ & 2 & Forest/dump & $\begin{array}{l}\text { Gravel; up to } 14,460 \mathrm{mg} \mathrm{kg}^{-1} \\
\quad \mathrm{~Pb}\end{array}$ \\
\hline & Radzimowice & Kaczawskie & $0-10$ & 10 & Forest/dump & Up to $27,500 \mathrm{mg} \mathrm{kg}^{-1} \mathrm{As}$ \\
\hline & $\begin{array}{r}\text { Radzimowice } \\
\text { (Olszanka) }\end{array}$ & Mts. & $0-10$ & 4 & $\begin{array}{l}\text { Forest (alluvium of mine } \\
\text { draining streams) }\end{array}$ & Up to $16,000 \mathrm{mg} \mathrm{kg}^{-1} \mathrm{As}$ \\
\hline & Rościszów & Sowie Mts. & $0-10$ & 3 & Forest/dump & Up to $3310 \mathrm{mg} \mathrm{kg}^{-1} \mathrm{~Pb}$ \\
\hline & Srebrna Góra & Sowie Mts. & $0-10$ & 9 & Forest/dump & Up to $57,300 \mathrm{mg} \mathrm{kg}^{-1} \mathrm{~Pb}$ \\
\hline & Złoty Stok & Złote Mts. & $0-10$ & 10 & Forest/dump & Up to $44,520 \mathrm{mg} \mathrm{kg}^{-1} \mathrm{As}$ \\
\hline & Złoty Stok & & $0-10$ & 6 & Slag dump & Up to $16,680 \mathrm{mg} \mathrm{kg}^{-1} \mathrm{As}$ \\
\hline & $\begin{array}{l}\text { Złoty Stok Trująca } \\
\text { valley }\end{array}$ & & $0-25$ & 4 & Grassland & Up to $3620 \mathrm{mg} \mathrm{kg}^{-1} \mathrm{As}$ \\
\hline \multirow[t]{4}{*}{$\begin{array}{l}\text { Copper } \\
\text { industry }\end{array}$} & $\begin{array}{l}\text { Legnica copper } \\
\text { smelter }\end{array}$ & $\begin{array}{l}\text { The Legnica } \\
\text { plain }\end{array}$ & $0-15$ & 5 & Forest & $\begin{array}{l}\text { Up to } 5250 \mathrm{mg} \mathrm{kg}^{-1} \mathrm{Cu} \text { and } \\
1125 \mathrm{mg} \mathrm{kg}^{-1} \mathrm{~Pb}\end{array}$ \\
\hline & $\begin{array}{l}\text { Głogów copper } \\
\text { smelter }\end{array}$ & $\begin{array}{l}\text { Dalkowskie } \\
\text { Hills }\end{array}$ & $0-15$ & 3 & Forest & $\mathrm{Up}$ to $1300 \mathrm{mg} \mathrm{kg}^{-1} \mathrm{Cu}$ \\
\hline & $\begin{array}{l}\text { Wartowice tailings } \\
\text { impoundment }\end{array}$ & $\begin{array}{l}\text { Bory } \\
\quad \text { Dolnośląskie }\end{array}$ & $0-15$ & 1 & Tailings impoundment & Up to $2790 \mathrm{mg} \mathrm{kg}^{-1} \mathrm{Cu}$ \\
\hline & $\begin{array}{l}\text { Żelazny Most } \\
\text { tailings } \\
\text { impoundment }\end{array}$ & $\begin{array}{l}\text { Lubińska } \\
\text { upland }\end{array}$ & $0-15$ & 4 & Tailings impoundment & Up to $1974 \mathrm{mg} \mathrm{kg}^{-1} \mathrm{Cu}$ \\
\hline \multirow[t]{2}{*}{$\begin{array}{l}\text { Shooting } \\
\text { range }\end{array}$} & Wrocław & $\begin{array}{l}\text { The Wroclaw } \\
\text { plain }\end{array}$ & $\begin{array}{l}0-10 \\
10-25\end{array}$ & $\begin{array}{r}12 \\
8\end{array}$ & $\begin{array}{l}\text { Grassland } \\
\text { Under grass }\end{array}$ & Up to $29,540 \mathrm{mg} \mathrm{kg}^{-1} \mathrm{~Pb}$ \\
\hline & Oleśnica & & $0-15$ & 5 & Forest & $\mathrm{Up}$ to $1388 \mathrm{mg} \mathrm{kg}^{-1} \mathrm{~Pb}$ \\
\hline \multirow[t]{3}{*}{ Landfills } & Swojczyce & Silesian plain & $0-25$ & 6 & Farmland, grassland & Municipal \\
\hline & Ziębicka & Silesian plain & $0-25$ & 8 & Grassland, woodland & From the gas plant/municipal \\
\hline & $\begin{array}{r}\text { Nowa Wieś } \\
\text { Legnicka }\end{array}$ & $\begin{array}{l}\text { The Legnica } \\
\text { plain }\end{array}$ & $0-10$ & 2 & Grassland, woodland & Wastes with unknown origin \\
\hline
\end{tabular}

digestion block, followed by titration with $\mathrm{FeSO}_{4}$ (ISO 14235 1998). Soil $\mathrm{pH}$ was determined potentiometrically in a suspension with $1 \mathrm{M} \mathrm{KCl} \mathrm{(w:v} \mathrm{1:1)} \mathrm{by} \mathrm{Seven}$ Compact S220 (Mettler Toledo) with InLab Expert ProISM combined electrode calibrated before the measurement with $\mathrm{pH}$ buffer solutions at $\mathrm{pH} 4.01$ and 7.00. In selected samples, the mineralogical composition of the soil samples (clay fraction) was studied by X-ray diffraction (XRD), utilizing a ARL X'tra by Thermo Electron diffractometer. Pseudototal concentrations of $\mathrm{Sb}$ in soils (Fig. 2) were determined by ICP-MS (8800 Triple Quad, Agilent Technologies, Japan) after microwave digestion of samples in aqua regia $\left(\mathrm{HNO}_{3}+\mathrm{HCl}\right.$, $1+3$ suprapure, Merck), according to US EPA 3051 procedure (US EPA 2007). The same procedure was used for blanks and certified reference materials: fresh 


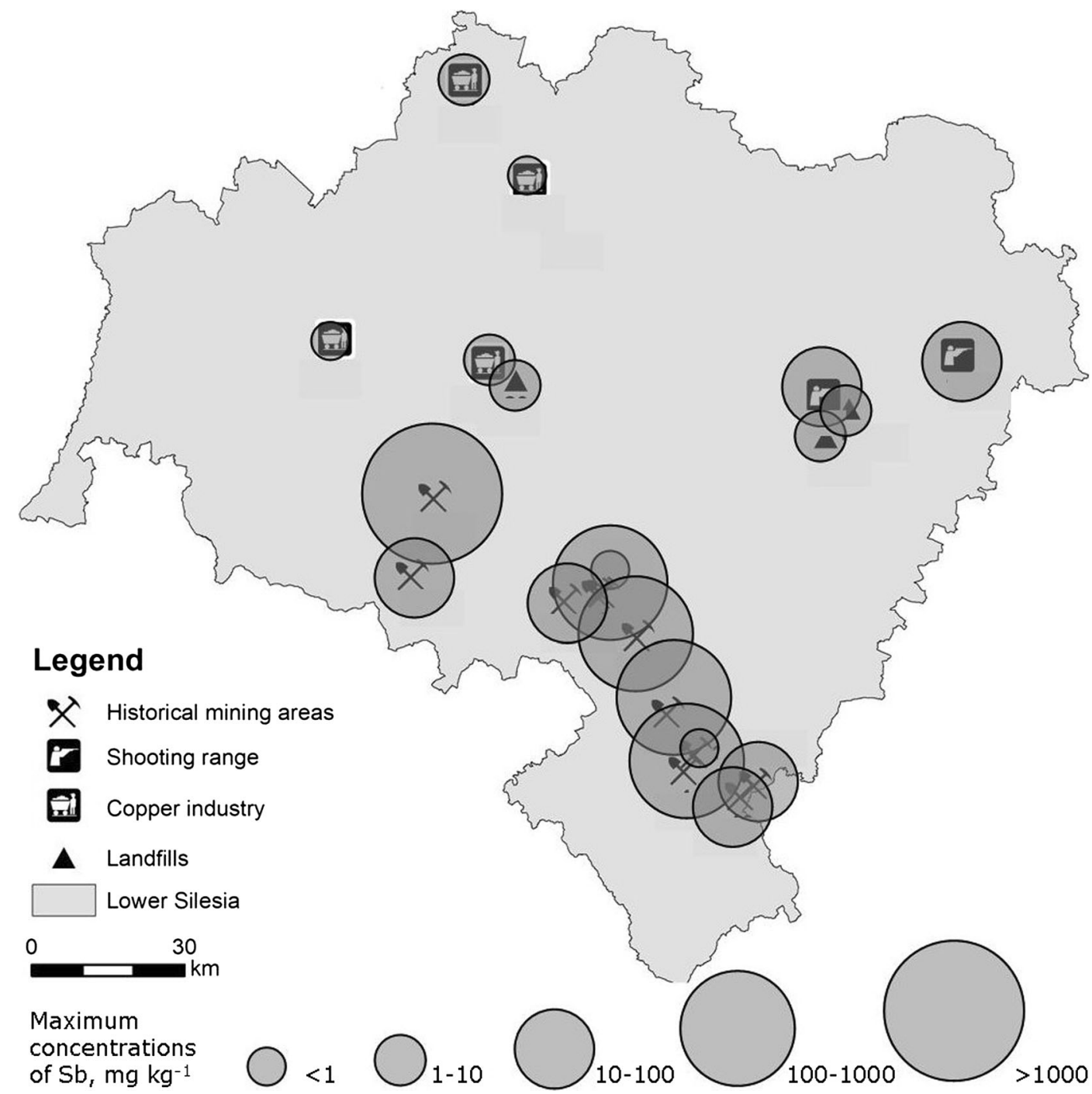

Fig. 2 Maximum concentrations of $\mathrm{Sb}$ in soils

water sediment (CNS 392) and soils CRM027 and CRM052, provided by Sigma-Aldrich.

\section{Calculation of pollution indices}

Two pollution indices: enrichment factor (EF) and geoaccumulation index $\left(I_{\text {geo }}\right)$, were calculated using the Formulas (1) and (2).

\section{Enrichment factor}

For calculation of EF (Formula 1), iron was used as a reference element. Its pseudototal concentrations in all samples were determined by ICP-MS after microwave digestion of samples in aqua regia, as described above for $\mathrm{Sb}$. These data were used as Cref values. The whole Earth crust was used as a reference environment, similarly as it was done by Sutherland (2000) and El-Badry and Khalifa (2017). Related concentrations of $\mathrm{Sb}$ and $\mathrm{Fe}$ in Earth crust (GBn and GBref) were set as $0.67 \mathrm{mg} \mathrm{kg}^{-1}$ and 5\%, respectively (Kabata-Pendias 2011). Based on $\mathrm{EF}$ values, five categories of soil contamination with $\mathrm{Sb}$ were distinguished (Table 1).

\section{Geoaccumulation index}

For calculation of $I_{\text {geo }}$ (Formula 2), various values of $\mathrm{Sb}$ geochemical background (GB) were used for soils that 
differed in texture, in order to meet the requirement of considering local or specific geological conditions. Accordingly, the values of GB were set as (1) sands$0.19 \mathrm{mg} \mathrm{kg}^{-1} \mathrm{Sb}$, (2) medium-textured soils (loams and silts) $-0.45 \mathrm{mg} \mathrm{kg}^{-1} \mathrm{Sb}$, and (3) heavy loams and clays - $0.6 \mathrm{mg} \mathrm{kg}^{-1} \mathrm{Sb}$ (Kabata-Pendias and Pendias 1999; Kabata-Pendias 2011).

Sequential extraction procedure

Nine samples, relatively rich in $\mathrm{Sb}$ and also few with lower content of $\mathrm{Sb}$ and representative for historical mining sites in Bystrzyca Górna, Dębowina, Dziećmorowice, Srebrna Góra, Złoty Stok, and Radzimowice, as well as three samples of shooting range soils from Wrocław and Oleśnica (Table 5) were selected for sequential extraction. The procedure (Wenzel et al. 2001) involves five extraction steps and additional washing that follows extraction in the steps 3 and 4 (Table 3).

After each extraction step, as well as after wash steps, the tubes were centrifuged for $15 \mathrm{~min}$ at $1700 \times \mathrm{g}$. Extracts were filtered through $0.45 \mu \mathrm{m}$ cellulose acetate filter paper and immediately analyzed by ICP-MS (8800 Triple Quad, Agilent Technologies, Japan) for the concentrations of Sb. Blanks were performed in the same procedure as soil samples. All extractions were performed in duplicate. Recovery of the SEP, calculated as differences between "near total" concentrations of $\mathrm{Sb}$ (determined after aqua regia digestion of soil) and the sums of all fractions, ranged between 89.3 and $109.2 \%$.

\section{Results and discussion}

Soil properties and total concentrations of $\mathrm{Sb}$

\section{Historical mining sites}

Soils collected in the mine dump sites contained high contribution (45-80\%) of skeletal fractions ( $>5 \mathrm{~mm}$ ), as roughly determined in the field (Karczewska et al. 2007, 2018,2019 ). The analysis of grain size distribution (in the $<2 \mathrm{~mm}$ fraction) performed in the laboratory showed that the dominant textural group in the earthy fraction of soil samples collected from the mine sites was sandy loam (Table 6). Those soils were considerably rich in organic matter. The maximum content of organic carbon was $17.4 \%$ (in Dębowina), and the mean value for all mine site soils examined was $3.2 \%$. Soil $\mathrm{pH}$ values ranged from 3.0 to 8.3 , a median $\mathrm{pH}$ was 4.1 , and most samples were assessed as strongly acidic. Such a low $\mathrm{pH}$ can be explained by the presence of sulfide minerals in the gangue rocks disposed on the dumps and their oxidation under propitious climatic factors. The mineralogical analysis (XRD) performed on selected samples showed that the main minerals present in clay fraction were quartz and phyllosilicates (kaolinite, illite, and chlorite). Additionally, gypsum and jarosite were found in the samples from Złoty Stok and Radzimowice, while iron oxides were highly abundant in Dębowina, Srebrna Góra, and Dziećmorowice. It should be noted that sulphides, mainly arsenopiryte, were identified in some samples (Złoty Stok and

Table 5 Soil samples selected for sequential extraction

\begin{tabular}{|c|c|c|c|c|c|c|}
\hline Location & Sampling site & Symbol & Textural group $^{\mathrm{a}}$ & $\mathrm{C}$ org. $\%$ & $\mathrm{pH}$ & Total Sb mg kg ${ }^{-1}$ \\
\hline \multirow[t]{9}{*}{ Historical mining sites } & Dębowina $(0-10 \mathrm{~cm})$ & D-1 & LS & 17.4 & 3.2 & 179 \\
\hline & Dębowina $(10-25 \mathrm{~cm})$ & D-2 & SL & 4.0 & 3.4 & 437 \\
\hline & Bystrzyca Górna & $\mathrm{B}$ & LS & 2.6 & 5.4 & 92.3 \\
\hline & Dziećmorowice & $\mathrm{DZ}$ & SL & 5.2 & 5.6 & 151 \\
\hline & Srebrna Góra & SG & $\mathrm{L}$ & 1.6 & 5.3 & 170 \\
\hline & Radzimowice & $\mathrm{R}-1$ & $\mathrm{~L}$ & 1.9 & 2.8 & 148 \\
\hline & Radzimowice (Olszanka) & $\mathrm{R}-2$ & $\mathrm{~L}$ & 3.6 & 7.1 & 5650 \\
\hline & Złoty Stok & ZS-1 & LS & 0.8 & 7.3 & 41.0 \\
\hline & Złoty Stok valley & $\mathrm{ZS}-2$ & SL & 4.7 & 6.0 & 29.5 \\
\hline \multirow[t]{3}{*}{ Shooting ranges } & Wrocław & W & $\mathrm{S}$ & 3.5 & 6.5 & 89.6 \\
\hline & Oleśnica 1 & $\mathrm{O} 1$ & $\mathrm{~S}$ & 0.1 & 8.0 & 4.15 \\
\hline & Oleśnica 4 & $\mathrm{O} 4$ & $\mathrm{~S}$ & 0.2 & 7.7 & 40.1 \\
\hline
\end{tabular}

${ }^{\text {a }} S$ sand, $L S$ loamy sand, $S L$ sandy loam, $L$ loam, $S i L$ silt loam 
ڤ人

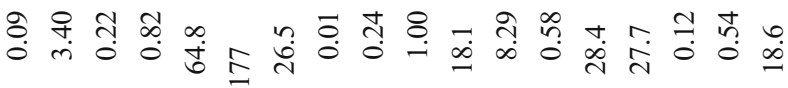

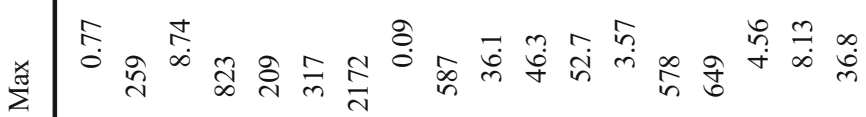

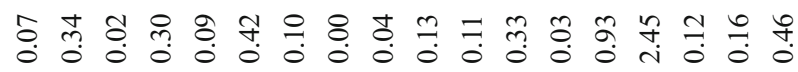

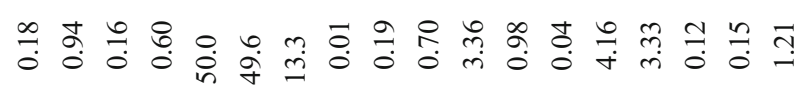

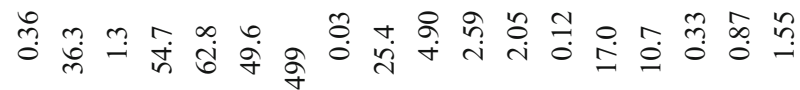

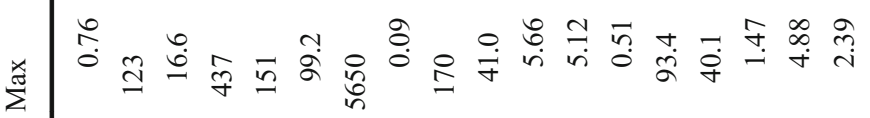

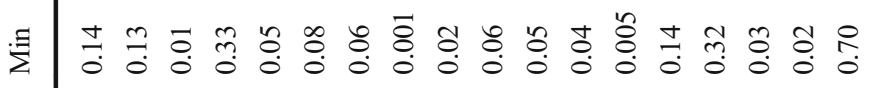
品 o.

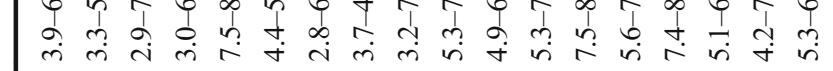

ते

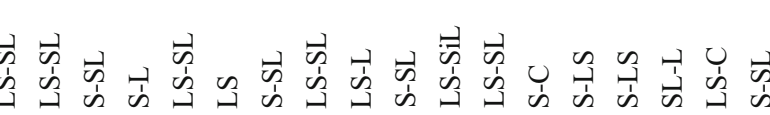

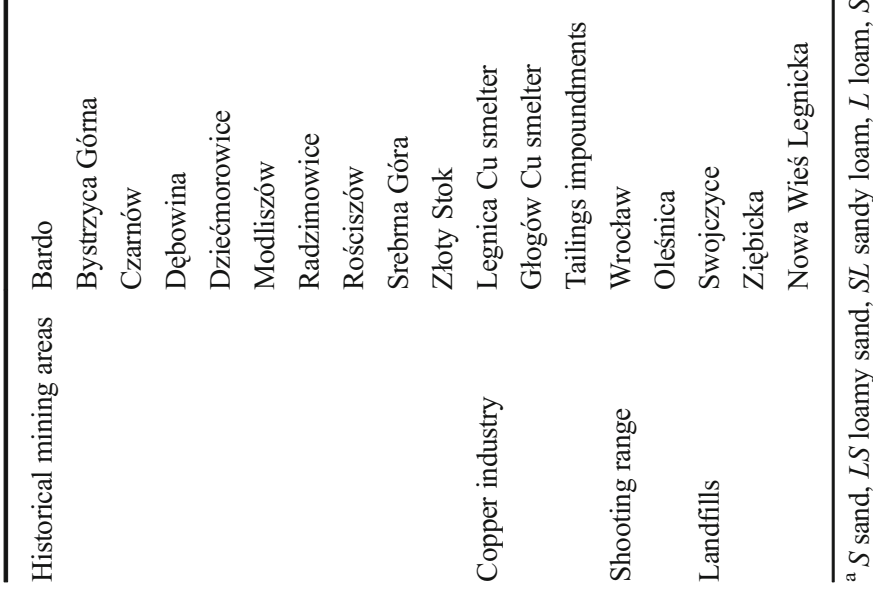


Dębowina), but none of Sb minerals were found. This effect can be attributed to limitations of XRD method that does not allow to detect mineralogical phases present in the amounts below $1 \%$. Therefore, further, more advanced mineralogical analyses will be needed.

The concentrations of $\mathrm{Sb}$ in soils of the mine sites differed considerably and ranged between 0.001 and $5650 \mathrm{mg} \mathrm{kg}^{-1}$. The lowest $\mathrm{Sb}$ concentrations were determined in Bardo and Rościszów. According to historical bibliographic sources, antimony ores accompanied by arsenic, copper, pyrite, and gold were acquired in those sites (Stysz et al. 2008, 2012), and the occurrence of $\mathrm{Sb}$ in waste dumps seemed very likely there; however, our survey showed that the waste rocks disposed in those sites were relatively poor in Sb. On the contrary, elevated concentrations of $\mathrm{Sb}$ were detected in soil samples collected from As mining sites in Czarnów and Złoty Stok, as well as from historical $\mathrm{Ag}$ and polymetallic ores mining sites in Srebrna Góra. Very high content of $\mathrm{Sb}$ in soils, over $100 \mathrm{mg} \mathrm{kg}^{-1}$, was also found in 10 samples collected from Dębowina, where stibnite was mined in eighteenth and nineteenth century, and in the samples that represented the zone of polymetallic mineralization in Bystrzyca Górna and Dziećmorowice. Quite unexpectedly, the maximum $\mathrm{Sb}$ concentration of all mine site samples, i.e., $5650 \mathrm{mg} \mathrm{kg}^{-1}$, was detected in alluvium of a stream supplied by mine drainage in the vicinity of polymetallic mine Radzimowice, and not in Dębowina. Moreover, very high concentrations of $\mathrm{Sb}$ were also found in mine dump soil samples collected in Radzimowice, which indicates that this area is not only extremely rich in As (Karczewska et al. 2007), the maximum soil concentration of which was determined as $192,500 \mathrm{mg} \mathrm{kg}^{-1} \mathrm{As}$ (unpublished data), but also in Sb. The co-occurrence of $\mathrm{As}$ and $\mathrm{Sb}$ in soils was confirmed to be a typical feature for mine dump soils in Dębowina and Radzimowice (Fig. 3). Similarly high concentrations of Sb in soils of mine sites were recorded from many regions in the world where antimony was mined, for instance from Scotland (Macgregor et al. 2015), China (Wei et al. 2015), or Italy (Cidu et al. 2014). However, in none of those sites, $\mathrm{Sb}$ co-occurred with such extremely high concentrations of As. For instance, in the surroundings of the Xikuangshan $\mathrm{Sb}$ mine in China, the very high concentrations of $\mathrm{Sb}$ in soils (441-1472 $\mathrm{mg} \mathrm{kg}^{-1}$ ) were accompanied by much lower content of As (32$354 \mathrm{mg} \mathrm{kg}^{-1}$ ) (Wei et al. 2015). Similarly, the samples from $\mathrm{Sb}$ mining sites in New South Wales in Australia contained 2735-4517 $\mathrm{mg} \mathrm{kg}^{-1} \mathrm{Sb}$ and $826-$ $1606 \mathrm{mg} \mathrm{kg}^{-1}$ As (Wilson et al. 2013).

It will not be a revealing statement that the waste rock material of metal ore mine sites is usually highly heterogeneous, and consequently, the soils that develop on the dumps in a given mining site can differ dramatically in their composition. Consequently, the concentrations of $\mathrm{Sb}$ in soils developed on such dumps show large differentiation (Table 6), depending on the kinds of gangue rocks, their geochemistry, and mining techniques.

\section{Copper industry}

The chemical properties of soil samples collected from copper tailings impoundments, their forelands, and from the surroundings of copper smelters differed strongly despite the fact that they had basically a common source of enrichment in metals and metalloids. The material collected from the Żelazny Most tailings impoundment had a sandy texture, while that from Wartowice represented clays. Also, the soils in the surroundings of two copper smelters showed a considerable diversity of their grain size distribution. The soils in the area of Głogów were relatively light, classified as sands and loamy sands, while in the surroundings of Legnica the dominant textural group of soils was silt loam (Table 6). The soil samples in this group were rather poor in organic carbon ( $1.5 \%$ on average), with the maximum content of $2.7 \%$ in a sample collected from the area of Legnica copper smelter, and negligible concentrations of organic matter in the tailings, particularly those from the Żelazny Most tailings impoundment. Soil $\mathrm{pH}$ values ranged from 4.9 to 8.0. Soils in the vicinity of copper smelters were predominantly acidic, while the $\mathrm{pH}$ of tailings was assessed as neutral to alkaline. High concentrations of $\mathrm{Cu}$ and $\mathrm{Pb}$ (Table 4) were a typical feature of all those soils, which indicated their enrichment in the elements originating from copper ores. The maximum concentrations of $\mathrm{Cu}$ and $\mathrm{Pb}$ in soils, i.e., $5254 \mathrm{mg} \mathrm{kg}^{-1}$ and $1125 \mathrm{mg} \mathrm{kg}^{-1}$, respectively, were recorded from the vicinity of the Legnica copper smelter. Similarly high concentrations were described by Cuske et al. (2017). The concentrations of $\mathrm{Cu}$ and $\mathrm{Pb}$ in tailings did not exceed $2800 \mathrm{mg} \mathrm{kg}^{-1} \mathrm{Cu}$ and $630 \mathrm{mg} \mathrm{kg}^{-1} \mathrm{~Pb}$. These data are comparable to those presented by Baran and Antonkiewicz (2017) and Karczewska et al. (2017). Notwithstanding a strong enrichment in $\mathrm{Cu}$ and $\mathrm{Pb}$, the soils in the surroundings of copper smelters did not 
Fig. 3 As and Sb co-occurrence in various types of deposits

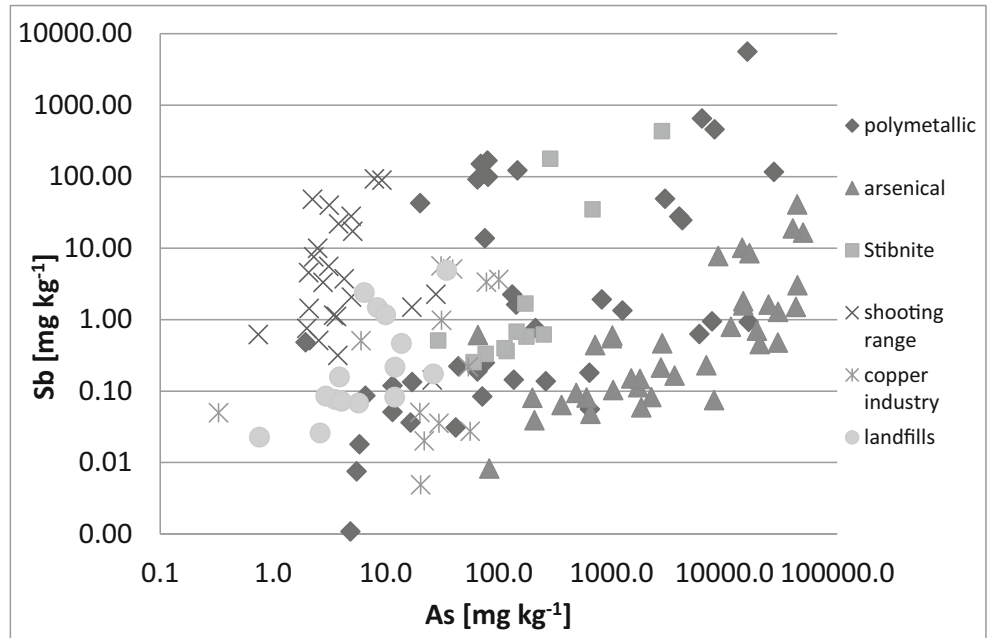

contain very high concentrations of $\mathrm{Sb}$, with the maximum value of $5.66 \mathrm{mg} \mathrm{kg}^{-1} \mathrm{Sb}$ in the sample collected in the neighborhood of Legnica and with an average value of $2.38 \mathrm{mg} \mathrm{kg}^{-1}$ (Table 6). Copper tailings were even poorer in $\mathrm{Sb}$, with the maximum concentration $0.51 \mathrm{mg} \mathrm{kg}^{-1}$. Based on the presented results, it can be stated that mining and processing of copper ores in Poland do not make a considerable source of antimony in the environment.

\section{Shooting ranges}

Two groups of shooting ranges examined in this study differed in their settings in a landscape. The shooting range Wrocław is located in the northern part of the city, in a close vicinity of residential buildings. The Oleśnica shooting range is surrounded by woodlands; however, the nearest houses are not very distant. This fact should be taken into account when assessing the environmental risk posed by soil pollution in those areas. Soil sampling sites were located mainly in the close proximities of firing points and backstops; however, the samples were also collected from other locations, throughout the entire areas of shooting ranges. All the samples had a sandy texture and were poor in organic carbon (Table 6). The average content of organic carbon in the shooting range soils was $1.6 \%$ and that in the samples from the Oleśnica shooting range was much lower, despite the fact that the facility has remained abandoned for over 30 years and is presently surrounded by woodlands. The $\mathrm{pH}$ of all soils in Wrocław was assessed as slightly acidic while that in the Oleśnica shooting range was neutral to alkaline, probably because of the occurrence of artifacts such as the pieces of concrete and bricks.

Much higher content of Sb in soils was recorded from the currently operating shooting range in Wrocław than in the soils of the historical shooting range. Particularly high soil concentrations of $\mathrm{Sb}$ were found in the area of backstop, with the maximum $93.4 \mathrm{mg} \mathrm{kg}-1$. What should be emphasized, some samples collected from a subsurface soil layer contained also considerably high concentrations of $\mathrm{Sb}$, up to $4.59 \mathrm{mg} \mathrm{kg}^{-1}$. The results obtained from our study are much lower than those reported from Switzerland, where shooting range soils contained even $8230 \mathrm{mg} \mathrm{kg}^{-1} \mathrm{Sb}$ (Robinson et al. 2008), but they are higher than those found in Norway, where the maximum soil concentration of $\mathrm{Sb}$ was $12 \mathrm{mg} \mathrm{kg}^{-1}$ (Okkenhaug et al. 2016).

\section{Landfills}

The samples were collected both from the surface layers of reclaimed landfills and from their surroundings. Three landfills examined in this study are surrounded by allotment gardens, arable fields, and wastelands. In the surrounding of the landfills Swojczyce and Nowa Wieś Legnicka, soil samples were collected from arable fields, while in the case of the Ziębicka landfill, the sampling sites were situated in its protection strip planted with trees as well as in allotment gardens and wastelands. The analysis of soil grain size distribution showed a variety of textural groups (Table 6). The concentrations of $\mathrm{Sb}$ in soils collected from the surroundings of landfills, as well as from their covering 
soil layers, were low, with the maximum $4.88 \mathrm{mg} \mathrm{kg}^{-1}$ $\mathrm{Sb}$ recorded from the Ziębicka landfill. The average concentration of $\mathrm{Sb}$ in soils of the Ziębicka landfill $\left(0.87 \mathrm{mg} \mathrm{kg}^{-1}\right)$ was higher compared to the Swojczyce landfill $\left(0.33 \mathrm{mg} \mathrm{kg}^{-1}\right)$, but lower than in Nowa Wieś Legnicka $\left(1.21 \mathrm{mg} \mathrm{kg}^{-1}\right)$. Such differences can be attributed to the kinds of wastes disposed in those sites. While the Swojczyce landfill collected almost exclusively municipal wastes, the Ziębicka landfill was additionally used for industrial purposes to dump the wastes produced by the railway operator and the gasworks. The facility in Nowa Wieś Legnicka was for a long time an illegal landfill where different wastes were dumped, very often of unknown origin. The diversity of $\mathrm{Sb}$ concentrations in landfill-affected soils can be ascribed to various properties of wastes. It should be stressed that the maximum values recorded in this study from such soils are considerably lower than those found in the surroundings of landfills where electronic wastes, plastics, and batteries were deposited (Gutiérrez- Gutiérrez et al. 2015; Okkenhaug et al. 2015; Mykolenko et al. 2018). On the other hand, however, the wastes dumped in well-protected disposal sites should not influence their surroundings. The concentrations of metals and metalloids in the soils neighboring with such landfills usually remain unaffected by their activity. For instance, the maximum concentrations of $\mathrm{Sb}$ in soils collected in the surroundings of the Seseña tire landfill in Spain, presented by Nadal et al. (2016), were as low as $0.06 \mathrm{mg} \mathrm{kg}^{-1}$.

To sum up an inventory part of this study, it should be stated that several locations in SW Poland turned out to have soils considerably enriched in Sb. It refers first of all to historical mining sites in Srebrna Góra, Dziećmorowice, Czarnów, Złoty Stok, and Radzimowice, as well as to the shooting ranges. The concentrations of $\mathrm{Sb}$ in those sites are usually highly heterogeneous, and the sites very rich in $\mathrm{Sb}$ are often spread in the areas slightly or moderately enriched. Therefore, it is particularly important to properly collect the representative soil samples with the purpose of environmental risk assessment. The maximum concentrations of Sb were found in Radzimowice, in the alluvium of a stream supplied with mine draining water, where $\mathrm{Sb}$ concentrations exceeded $5600 \mathrm{mg} \mathrm{kg}^{-1}$. The lowest concentrations of $\mathrm{Sb}$, below $1.11 \mathrm{mg} \mathrm{kg}^{-1}$, were determined in the areas of landfills and their surroundings, in copper tailings and in two mine sites previously supposed to represent Sb-rich mineralization: Bardo and
Rościszów. Those areas can be considered as uncontaminated by $\mathrm{Sb}$.

The average concentration of $\mathrm{Sb}$ calculated for all soil samples in the studied areas was $21.8 \mathrm{mg} \mathrm{kg}^{-1}$ and was over 20 times higher than the mean $\mathrm{Sb}$ concentrations in Polish soils obtained from the monitoring networks (Pasieczna 2012; Kabata-Pendias 2011). It was also much higher than the average content of $\mathrm{Sb}$ in European soils provided by Salminen et al. (2005). The results show that the sites enriched in $\mathrm{Sb}$ have been rightly appointed for the purpose of general recognition. The study confirmed that there are various sites in Lower Silesia where soils contain relatively high concentrations of Sb. However, assuming that a permissible limit for total soil As was $40 \mathrm{mg} \mathrm{kg}^{-1}$, i.e., the value of the Norwich proposal (Okkenhaug et al. 2016), only 19 of all sites examined would be considered as polluted with $\mathrm{Sb}$. Moving the limit to $100 \mathrm{mg} \mathrm{kg}^{-1}$, as in Dutch list (van Leeuwen and Aldenberg 2012), we could conclude that the real problem of undue concentrations of $\mathrm{Sb}$ in soils occurred in only nine of the sites examined.

Indices of soil enrichment in $\mathrm{Sb}$

\section{Enrichment factor}

The values of enrichment factor $\mathrm{EF}$ for $\mathrm{Sb}$ in all soil samples under study are presented in Table 6. The maximum EF values, up to 2172 , were recorded from Radzimowice, the area extremely enriched in $\mathrm{Sb}$ and $\mathrm{As}$. Very high factors were also obtained for Dębowina, up to 822 , and for the soils of shooting ranges in Oleśnica and Wrocław, up to 649 and 578, respectively. The values of EF over 40 that should be classified as the extreme enrichment (Table 1) were also obtained for individual sites in Srebrna Góra (EF up to 587), Dziećmorowice (EF up to 209), Bystrzyca Górna (EF up to 167), and in the surroundings of Głogów copper smelter $(E F=53)$. Twenty-five samples were altogether classified as very highly and significantly enriched (EF 20-40). They were collected in the areas of Złoty Stok, Srebrna Góra, Modliszów, and Czarnów, as well as in both shooting ranges and in the neighborhoods of copper smelters. Eleven soil samples fell into the class of moderate enrichment (EF 2-5) that included several sites in the areas listed above, as well as the tailings in Żelazny Most and two landfills in Wrocław. Seventyseven samples were classified as unpolluted, with $\mathrm{EF}<$ 2, though $50 \%$ of collected samples had the EF $>2$ and 
were classified as contaminated, so they make a potential source of $\mathrm{Sb}$ in the environment.

\section{Geoaccumulation index}

The values of $I_{\text {geo }}$ are shown in Table 6. According to those values, the quality of 27 soil samples should be classified as extremely strongly polluted (class $6, I_{\text {geo }}>$ 5), with the maximum of $I_{\text {geo }}=13$ in Radzimowice, in the alluvial soil affected by mine draining water. The other soil samples categorized in the 6th class of $\mathrm{Sb}$ geoaccumulation were those collected from historical mining sites in Dębowina, Srebrna Góra, Dziećmorowice, Bystrzyca Górna, and Złoty Stok, as well as in the shooting ranges. Five samples collected from shooting ranges were qualified to the class 5 : strong to very strongly contaminated. Six samples that represented the shooting ranges and Czarnów mine site were qualified to the class 4 : strongly contaminated, and further 14 samples, collected from the surroundings of copper smelters and one landfill in Wrocław - to the class 3: moderate to strongly polluted $\left(2<I_{\text {geo }}<3\right)$. Based on $I_{\text {geo }}, 96$ samples that made over $60 \%$ of the whole collection should be assessed as uncontaminated. It means, however, that nearly $40 \%$ of the samples bore the evident signs of an industrial, human-made impact.

Both indices, EF and $I_{\text {geo }}$, showed high or very high soil pollution with $\mathrm{Sb}$ in the areas of historical mining activity as well as in shooting ranges. Those indices indicate a considerable environmental risk, as the values of EF $>20$ and $I_{\text {geo }}>2$ correspond with very high values of ecological risk index (Cai et al. 2015). It should be stressed, however, that a real scale of soil contamination in those areas is in fact not known. Soil enrichment with $\mathrm{Sb}$, and with other potentially toxic elements, has most likely patchy or spotty patterns, which makes its assessment very difficult. Moreover, a release of $\mathrm{Sb}$ from soils is not monitored in any of the sites recognized as strongly contaminated.

\section{Sequential extraction}

The results of sequential extraction analysis, performed on 12 samples representative of the most enriched areas, are presented in Fig. 4. The sum of fractions 1 and 2 can be considered as easily mobilizable and therefore potentially dangerous to the environment. The highest percentage of potentially available $\mathrm{Sb}$ was found in a sample $\mathrm{O} 1$ collected from the Oleśnica shooting range, where the sum of fractions 1 and 2 reached $30 \%$ of total $\mathrm{Sb}$, determined in aqua regia. This contribution should be assessed as extremely high compared to the results obtained by other researchers (Müller et al. 2007; Ettler et al. 2010). However, it should be stressed that the soil $\mathrm{O} 1$ was relatively poor in $\mathrm{Sb}$ and its total concentration in this soil was as low as $4.15 \mathrm{mg} \mathrm{kg}^{-1}$. Therefore, the absolute amount of $\mathrm{Sb}$ present in those two fraction, expressed in milligram per kilogram, remains in fact very low. Two other shooting range soils ( $\mathrm{W}$ and $\mathrm{O} 4$ ) contained $10.9 \%$ and $10.6 \%$ of $\mathrm{Sb}$ in the fractions 1 and 2 , respectively, which means that their sum made 9.8 and $4.3 \mathrm{mg} \mathrm{kg}^{-1}$, respectively. These values should be considered as relatively high. Müller et al. (2007) received almost $10 \%$ of sum first and second fraction by sequential extraction in samples collected in the area of historical copper mining and smelting in Harz Mountains in Germany. In our study, similar percentage of the fractions $1+2(9.6-10.9 \%)$ was obtained from sequential extraction of $\mathrm{Sb}$ performed in the samples collected in Srebrna Góra (SG), Złoty Stok valley (ZS-2), and in Wrocław shooting range (W). Substantially lower (below $4.5 \%$ ) was the potential solubility of $\mathrm{Sb}$ in the soils collected from the mine sites in Złoty Stok (ZS-1), Dębowina (D; both depths), and Dziećmorowice (DZ). Ettler et al. (2010) obtained quite comparable results from the sequential extraction of $\mathrm{Sb}$ in soils that represented the area of polymetallic ore mining and processing in Czech Republic. Those soils contained approximately $1.3-5.8 \%$ of $\mathrm{Sb}$ in the fractions 1 and 2 . What is important for the assessment of environmental risk, the soils in Złoty Stok contain additionally high concentrations of As. The area is known as strongly polluted with arsenic, and numerous previous studies showed its high potential mobility (Krysiak and Karczewska 2007; Karczewska et al. 2007, 2013; Lewińska et al. 2018). The soils influenced by mining in Czarnów and Radzimowice (Karczewska et al. 2007) as well as those in Dębowina (unpublished data) are also considerably polluted with arsenic. It should be stressed therefore that potentially soluble fractions of both these elements will likely act together as environmental risk factors.

The lowest contributions of easily mobilizable $\mathrm{Sb}$ were found in mine dump soils $\mathrm{R}$ (both samples) and $\mathrm{B}$, i.e., in the soils from Radzimowice (R-1 and R-2: 1.0 and $1.3 \%$, respectively) and Bystrzyca Górna (1.1\%), as well as in the samples collected from the site of former stibnite mine in Dębowina (D-1 and D-2: 2.8 and 1.7\%, respectively). However, considerably low contributions 
Fig. $4 \mathrm{Sb}$ speciation in soils determined in sequential extraction. Fractions: 1. nonspecifically sorbed (easily soluble), 2. specifically sorbed, 3 . bound to amorphous and poorlycrystalline hydrous oxides of Fe and $\mathrm{Al}, 4$. bound to wellcrystalline hydrous oxides of Fe and $\mathrm{Al}, 5$. residual
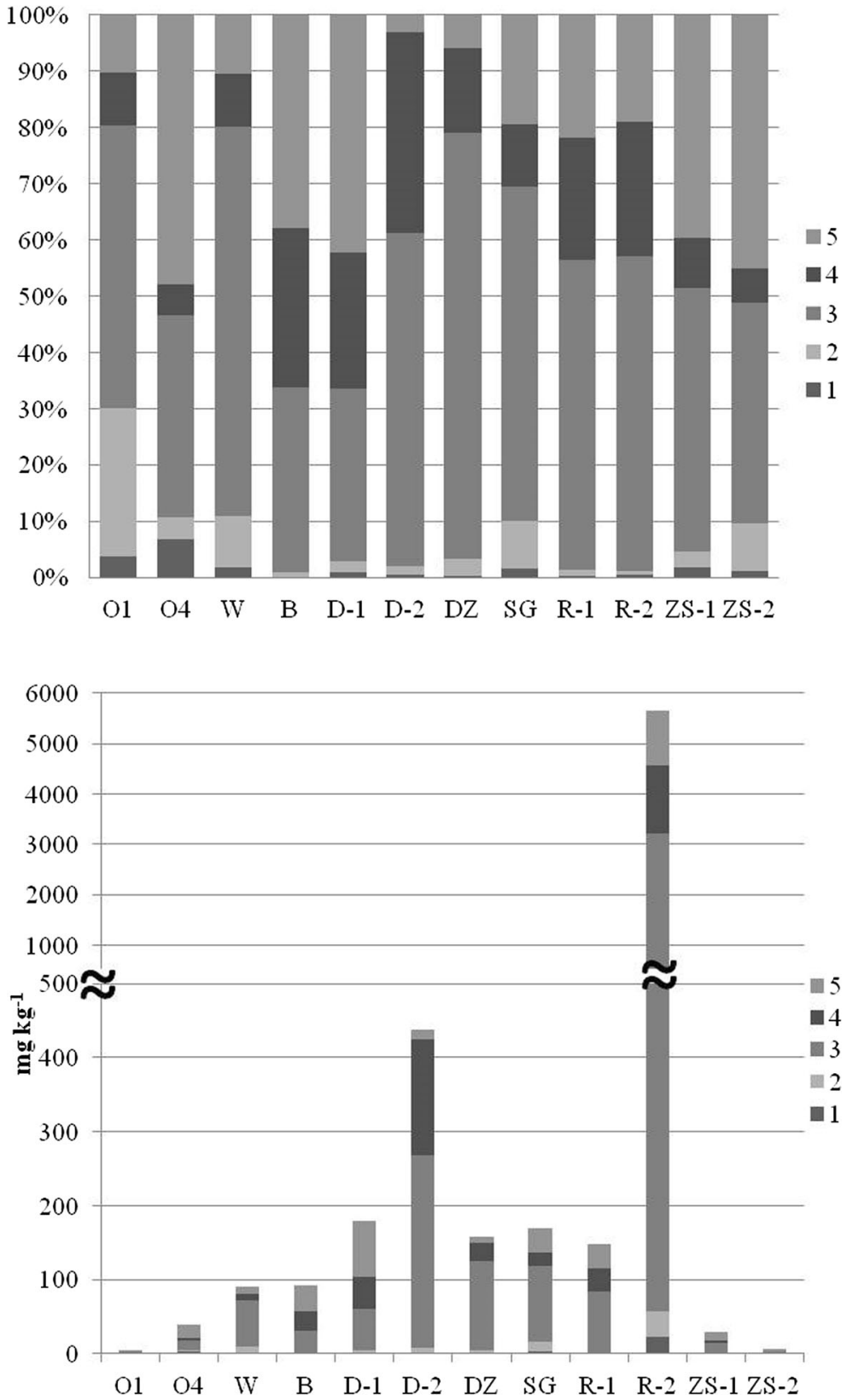

of $\mathrm{Sb}$ in the fractions 1 and $2(1 \%)$ in the sample R-2 made as much as $57.5 \mathrm{mg} \mathrm{kg}^{-1}$ of easily soluble $\mathrm{Sb}$. In all the samples examined, independently of their origin, $\mathrm{Sb}$ was bound predominantly in the fraction 3 , the content of which was in the range $37-75 \%$ of total $\mathrm{Sb}$ concentrations. This fraction, believed to be made mainly by $\mathrm{Sb}$ bound to amorphous $\mathrm{Mn}$ and $\mathrm{Fe}$ (hydro)oxides, should also be considered as potentially soluble, because it can be mobilized in reducing conditions. Similarly, the fraction 4 , bound to crystalline oxides, that made in our soils from 6.2 to $38 \%$ of total $\mathrm{Sb}$ can be released to soil solution in anoxic environment. The lowest percentage of $\mathrm{Sb}$ in the fraction 4 , below $9.5 \%$, was found in the samples collected from shooting ranges as well as from the arsenic mine dump in Złoty Stok (ZS-1). The highest amounts of Sb bound to the crystalline oxides (fraction 4) were determined in the old mine dumps in Debowina, Bystrzyca Górna, and Radzimowice. Several studies confirmed that $\mathrm{Sb}$, similarly to As, may be released from soils through reductive 
dissolution of $\mathrm{Mn}$ and $\mathrm{Fe}$ (hydro)oxides under waterlogged conditions (Wilson et al. 2010; Tandy et al. 2018). Such processes would not, however, take place in most of the soils identified as enriched in $\mathrm{Sb}$ in this study, as they are not at risk of flooding, except for the alluvial soils in Radzimowice and the valley in Złoty Stok. Moreover, Sb released from the soil solid phase in such conditions would likely be resorbed on undissolved or on re-precipitating Fe hydroxides, due to the fact that a reduced form of $\mathrm{Sb}$, i.e., $\mathrm{Sb}$ (III), is usually much more strongly sorbed than $\mathrm{Sb}(\mathrm{V})$ (Leuz et al. 2006; Mitsunobu et al. 2006; Filella et al. 2009; Wilson et al. 2010).

\section{Conclusions}

This study was designed mainly as a screening based on examination of various sites selected as likely enriched in Sb. The results confirmed that there are several localities in Lower Silesia and the Sudetenland where soils contain elevated or even high concentrations of Sb. Those localities represented first or all the historical mine sites in which $\mathrm{As}, \mathrm{Sb}$, or polymetallic ores were acquired, as well as military shooting ranges. The study did not involve any advanced examination of a spatial distribution of soil enrichment with $\mathrm{Sb}$ or a real extent of pollution, but it indicated the sites where soil Sb concentrations and pollution indices were particularly high. Those sites should be examined more thoroughly in order to properly assess a related environmental risk. High percentage of $\mathrm{Sb}$ that was extracted from some samples in the fractions 1 and 2 of sequential extraction procedure provides a strong premise for further risk- and remediation-oriented examination of those soils. It refers particularly to the shooting range soils, the mine sites in Radzimowice, and Srebrna Góra, with special focus on alluvial soils in Radzimowice and the valley affected by arsenic mine tailings in Złoty Stok. A comprehensive assessment of environmental risk will be particularly important and should be urgently made in the case of shooting range soils, in which the enrichment in $\mathrm{Sb}$ is accompanied by very high contamination with $\mathrm{Pb}$, as well as for alluvial soils highly polluted by As and prone to waterlogging. Based on pollution indices, attention should also be paid to the areas affected by historical mining in Dziećmorowice, Dębowina, and Modliszów. Those sites should be included into more advanced study aimed to determine the scale of soil contamination and to choose the most appropriate methods of remediation, considering first of all those based on immobilization of $\mathrm{Sb}$ and heavy metals using iron compounds. On the other hand, we can conclude that the tailings disposed in copper industry-associated impoundments do not indicate any particular enrichment in Sb. Furthermore, the extent of soil pollution with $\mathrm{Sb}$ in the surroundings of copper smelters and three Lower Silesian landfills can be assessed as very low and negligible from the standpoint of potential environmental risk.

Acknowledgements This research was supported by the National Science Centre of Poland [Project No. 2014/13/B/ST10/ 02978].

Open Access This article is distributed under the terms of the Creative Commons Attribution 4.0 International License (http:// creativecommons.org/licenses/by/4.0/), which permits unrestricted use, distribution, and reproduction in any medium, provided you give appropriate credit to the original author(s) and the source, provide a link to the Creative Commons license, and indicate if changes were made.

Publisher's note Springer Nature remains neutral with regard to jurisdictional claims in published maps and institutional affiliations.

\section{References}

Baran, A., \& Antonkiewicz, J. (2017). Phytotoxicity and extractability of heavy metals from industrial wastes. Environment Protection Engineering, 43(2), 143-155.

Barker, A. J., Douglas, T. A., Ilgen, A. G., \& Trainor, T. P. (2019). Lead and antimony from bullet weathering in newly constructed target berms: chemical speciation, mobilization, and remediation strategies. Science of the Total Environment, $658,558-569$.

Cai, C., Xiong, B., Zhang, Y., Li, X., \& Nunes, L. M. (2015). Critical comparison of soil pollution indices for assessing contamination with toxic metals. Water, Air, \& Soil Pollution, 226(10), 352.

Chang, A., Pan, G., Page, A. L., Asano, T. (2002). Developing human health-related chemical guidelines for reclaimed water and sewage sludge applications in agriculture. World Health Organization: Division of Environmental Health. h t t p : / / c i t e s e e r x. i s t.p s u . edu/viewdoc/download?doi=10.1.1.472.6179\&rep=rep1 \&type=pdf. Accessed 09 Oct 2018.

Cidu, R., Biddau, R., Dore, E., Vacca, A., \& Marini, L. (2014). Antimony in the soil-water-plant system at the Su Suergiu abandoned mine in Sardinia, Italy: strategies to mitigate contamination. Science of the Total Environment, 497-498, 319-331. 
Courtin-Nomade, A., Rakotoarisoa, O., Bril, H., Grybos, M., Forestier, L., Foucher, F., \& Kunz, M. (2012). Weathering of Sb-rich mining and smelting residues: insight in solid speciation and soil bacteria toxicity. Chemie der Erde, 72(S4), 29-39.

Cuske, M., Karczewska, A., Matyja, K., \& Gałka, B. (2017). Ecotoxicity and phytotoxicity of soil solutions extracted from $\mathrm{Cu}$-contaminated soils amended with organic waste materials. Fresenius Environmental Bulletin, 26(1a), 1163-1173.

El-Badry, A. E.-M. A., \& Khalifa, M. M. (2017). The occurrence and distribution of high-arsenic, selenium, tin and antimony in bottom sediments of Burullus lagoon and its effects on human health, Egypt. Journal of African Earth Science, 136, 305-311.

El-Fadel, M., Bou-Zeid, E., Chahine, W., \& Alayli, B. (2002). Temporal variation of leachate quality from pre-sorted and baled municipal solid waste with high organic and moisture content. Waste Management, 22, 269-282.

Ettler, V., Tejnecký, V., Mihaljevič, M., Šebek, O., Zuna, M., \& Vanĕk, A. (2010). Antimony mobility in lead smelterpolluted soils. Geoderma, 155, 409-418.

Filella, M., Belzile, N., \& Chen, Y.-W. (2002). Antimony in the environment: a review focused on natural waters $\mathrm{I}$. Occurrence. Earth-Science Reviews, 57, 125-176.

Filella, M., Williams, P. A., \& Belzile, N. (2009). Antimony in the environment: knowns and unknowns. Environmental Chemistry, 6(2), 95-105.

Földi, C., Sauermann, S., Dohrmann, R., \& Mansfeldt, T. (2018). Traffic-related distribution of antimony in roadside soils. Environmental Pollution, 237, 704-712.

Fu, Z., Wu, F., Mo, C., Deng, Q., Meng, W., \& Giesy, J. (2016). Comparison of arsenic and antimony biogeochemical behavior in water, soil and tailings from Xikuangshan, China. The Science of the Total Environment, 539, 97-104.

Gee, G., \& Bauder, J. W. (1986). Particle-size analysis. In A. Klute (Ed.), Methods of analysis. Part I agronomy series 9 (pp. 383-409). Madison: American Society of Agronomy, Inc., Soil Science Society of America, Inc. Publisher.

Gutiérrez- Gutiérrez, S. C., Coulon, F., Jiang, Y., \& Wagland, S. (2015). Rare earth elements and critical metal content of extracted landfilled material and potential recovery opportunities. Waste Management, 42, 128-136.

He, M. (2007). Distribution and phytoavailability of antimony at an antimony mining and smelting area, Hunan, China. Environmental Geochemistry and Health, 29(3), 209-219.

Hiller, E., Lalinská, B., Chovan, M., Jurkovič, L., Klimko, T., Jankulár, M., Hovorič, R., Šottník, P., Fl'aková, R., Ženišová, Z., \& Ondrejková, I. (2012). Arsenic and antimony contamination of waters, stream sediments and soils in the vicinity of abandoned antimony mines in the Western Carpathians, Slovakia. Applied Geochemistry, 27(3), 598614.

Hu, X., He, M., \& Li, S. (2015). Antimony leaching release from brake pads: effect of $\mathrm{pH}$, temperature and organic acids. Journal of Environmental Sciences, 29, 11-17.

ISO 14235. (1998). Soil quality - determination of organic carbon by sulfochromic oxidation. Geneva: Organization for Standardization.

Johnson, C. A., Moench, H., Wersin, P., Kugler, P., \& Wenger, C. (2005). Solubility of antimony and other elements in samples taken from shooting ranges. Journal of Environmental Quality, 34(1), 248-254.

Kabała, C. (2015). Soils of Lower Silesia: origins, diversity and protection. PTG. PTSH. Wrocław. http://www.org.up.wroc. p1/igosr/PTG29/monografia.pdf. Accessed 09 Oct 2018.

Kabata-Pendias, A. (2011). Trace elements in soils and plants (4th ed.). Boca Raton: CRC Press.

Kabata-Pendias, A., Pendias H. (1999). Biogechemistry of trace elements. PWN Warszawa (in Polish).

Karczewska, A. (1996). Metal species distribution in top- and subsoil in the area affected by copper smelters. Applied Geochemistry, 11(1/2), 35-42.

Karczewska, A., Bogda, A., \& Krysiak, A. (2007). Arsenic in soils in the areas of former mining and mineral processing in Lower Silesia, southwestern Poland. Trace Metals and other Contaminants in the Environment, 9, 411-440.

Karczewska, A., Krysiak, A., Mokrzycka, D., Jezierski, P., \& Szopka, K. (2013). Arsenic distribution in soils of a former As mining area and processing. Polish Journal of Environmental Studies, 22(1), 175-181.

Karczewska, A., Kaszubkiewicz, J., Kabała, C., Jezierski, P., Spiak, Z., \& Szopka, K. (2017). Tailings impoundments of Polish copper mining industry - environmental effects, risk assessment and reclamation. In J. Bech, C. Bini, \& M. Pashkevich (Eds.), Assessment, restoration and reclamation of mining influenced soils (pp. 149-202). Amsterdam: Elsevier.

Karczewska, A., Lewińska, K., Siepak, M., Gałka, B., Dradrach, A., \& Szopka, K. (2018). Transformation of beech forest litter as a factor that triggers arsenic solubility in soils developed on historical mine dumps. Journal of Soils and Sediments, 18(8):2749-2758.

Karczewska, A., Lewińska, K., Siepak, M., Gałka, B. (2019). Lanthanides in soils of historical mining sites in the Sudetes, SW Poland. Polish Journal of Environmental Studies (in press).

Kowalska, J., Mazuerk, R., Gąsiorek, M., Setlak, M., Zaleski, T., \& Waroszewski, J. (2016). Soil pollution indices conditioned by medieval metallurgical activity - a case study from Krakow (Poland). Environmental Pollution, 218, 10231036.

Kowalska, J., Mazurek, R., Gąsiorek, M., \& Zaleski, T. (2018). Pollution indices as useful tools for the comprehensive evaluation of the degree of soil contamination-a review. Environmental Geochemistry and Health, 40, 2395-2420. https://doi.org/10.1007/s10653-018-0106-z.

Krysiak, A., \& Karczewska, A. (2007). Arsenic extractability in soils in the areas of former arsenic mining and smelting, SW Poland. Science of the Total Environment, 379(2), 190-200.

Laporte-Saumure, M., Martel, R., \& Mercier, G. (2011). Characterization and metal availability of copper, lead, antimony and zinc contamination at four Canadian small arms firing ranges. Environmental Technology, 32(7-8), 767-781.

Leuz, A. K., Monch, H., \& Johnson, C. A. (2006). Sorption of $\mathrm{Sb}$ (III) and $\mathrm{Sb}(\mathrm{V})$ to goethite: influence on $\mathrm{Sb}$ (III) oxidation and mobilization. Environmental Science and Technology, 40, 7277-7282.

Lewińska, K., Karczewska, A., Siepak, M., Gałka, B., Stysz, M., \& Kaźmierowski, C. (2017). Recovery and leachability of antimony from mine- and shooting range soils. Journal of Elementology, 22(1), 70-90. 
Lewińska, K., Karczewska, A., Siepak, M., \& Gałka, B. (2018). Potential of Fe-Mn wastes produced by a water treatment plant for arsenic immobilization in contaminated soils. Journal of Geochemical Exploration, 184(B), 226-231.

Li, J., Zhang, B., He, Y., Zhou, Y., Chen, X., Ruan, S., Yang, Y., Dai, C., \& Tang, L. (2018). Antimony contamination, consequences and removal techniques: a review. Ecotoxicology and Environmental Safety, 156, 125-134.

Loska, K., Wiechuła, D., \& Korus, I. (2004). Metal contamination of farming soils affected by industry. Environment International, 30(2), 159-165.

Macgregor, K., MacKinnon, G., Farmer, J. G., \& Graham, M. C. (2015). Mobility of antimony, arsenic and lead at former antimony mine, Glendinning, Scotland. The Science of the Total Environment, 529, 213-222.

Mączka, M., \& Stysz, M. (2008). The mine "Reiche Silber Glück" in Dębowina - the relic of past antimony mining in the Bardzkie Mountains. In P. P. Zagożdzon \& M. Madziarz (Eds.), Dzieje górnictwa - element europejskiego dziedzictwa kultury. History of mining - the part of European cultural heritage (pp. 213-226). Wrocław: Wydawnictwo Politechniki Wrocławskiej (in Polish, with English abstract).

Mączka, M., \& Stysz, M. (2013). Bardo - miasto z górniczą przeszłością. In P. P. Zagożdzon \& M. Madziarz (Eds.), Dzieje i historia górnictwa - oraz wykorzystanie pozostałości dawnych robót górniczych (pp. 11-12). Wrocław: Wydawnictwo Politechniki Wrocławskiej (in Polish, with English abstract).

Mikulski, S. Z. (2010). The characteristic and genesis of the goldbearing arsenic and polymetallic mineralization in the Czarnów deposit (Western Sudetes). Biuletyn Państwowego Instytutu Geologicznego, 439, (in Polish, with English abstract).

Mitsunobu, S., Harada, T., \& Takahashi, Y. (2006). Comparison of antimony behavior with that of arsenic under various soil redox conditions. Environment Science and Technology, 40, $7270-7276$.

Müller, G. (1986). Schadstoffe in Sedimenten - Sedimente als Schadstoffe. Umweltgeologie-Band, 79, 107-126 (in German).

Müller, K., Daus, B., \& Morgenstern, P. (2007). Mobilization of antimony in soil and sediment samples - evaluation of different leaching procedures. Water, Air and Soil Pollution, 183, 427-436.

Mykolenko, S., Liedienov, V., Kharytonov, M., Makieieva, N., Kuliush, T., Queralt, I., Marguí, E., Hidalgo, M., Pardini, G., \& Gispert, M. (2018). Presence, mobility and bioavailability of toxic metal(oids) in soil, vegetation and water around $\mathrm{a} \mathrm{Pb}-$ $\mathrm{Sb}$ recycling factory (Barcelona, Spain). Environmental Pollution, 237, 569-580.

Nadal, M., Rovira, J., Díaz-Ferrero, J., Schuhmacher, M., \& Domingo, J. L. (2016). Human exposure to environmental pollutants after a tire landfill fire in Spain: health risk. Environment International, 97, 37-44.

Nejbert, K., Siuda, R., Borzęcki, R., Matyszczak, W. (2013). Mineralogy of antimony ores mined at Dębowina in the Bardzkie Mts (Sudetes). SW Poland. Mineralogia - Special papers, 41, 68.

Okkenhaug, G., Zhu, Y.-G., Luo, L., Lei, M., Li, X., \& Mulder, J. (2011). Distribution, speciation and availability of antimony
$\mathrm{Sb})$ in soils and terrestrial plants from an active $\mathrm{Sb}$ mining area. Environmental Pollution, 159, 2427-2434.

Okkenhaug, G., Almås, Å. R., Morin, N., Hale, S. E., \& Arp, H. P. H. (2015). The presence and leachability of antimony in different wastes and waste handling facilities in Norway. Environmental Sciences: Processes and Impacts, 17(11), 1880-1891.

Okkenhaug, G., Grasshorn Gebhardt, K.-A., Amstaetter, K., Lassen, Bue, H., Herzel, H., Mariussen, E., Rossebø Almås, Å., Cornelissen, G., Breedveld, G. D., Rasmussen, G., \& Mulder, J. (2016). Antimony (Sb) and lead (Pb) in contaminated shooting range soils: $\mathrm{Sb}$ and $\mathrm{Pb}$ mobility and immobilization by iron based sorbents, a field study. Journal of Hazardous Materials, 307, 336-343.

Pasieczna, A. (2012). Contents of antimony and bismuth in agricultural soils of Poland. Polish Journal of Agronomy, 10, 2129.

Reimann, C., Matschullat, J., Birke, M., \& Salminen, R. (2010). Antimony in the environment: lessons from geochemical mapping. Applied Geochemistry, 25, 175-198.

Robinson, B. H., Bischofberger, S., Stoll, A., Schroer, D., Furrer, G., Roulier, S., Gruenwald, A., Attinger, W., \& Schlin, R. (2008). Plant uptake of trace elements on a Swiss military shooting range: uptake pathways and land management implications. Environmental Pollution, 153, 668-676.

Salminen, R., Plant, J. A., Reeder, S. (2005). Geochemical atlas of Europe. Part 1, Background information, methodology and maps, Espoo: Geological survey of Finland, p. 526.

Sanderson, P., Naidu, R., Bolan, N., Bowman, M., \& Mclure, S. (2012). Effect of soil type on distribution and bioaccessibility of metal contaminants in shooting range soils. Science of the Total Environment, 438, 452-462.

Soil Survey Staff (1999). Soil taxonomy: a basic system of soil classification for making and interpreting soil surveys (2nd edn) Natural Resources Conservation Service. United States Department of Agriculture (USDA) handbook 436.

Spuller, C., Weigand, H., \& Marb, C. (2007). Trace metal stabilization in a shooting range soil: mobility and phytotoxicity. Journal of Hazardous Materials, 141(2), 378-387.

Steely, S., Amarasiriwardena, D., \& Xing, B. (2007). An investigation of inorganic antimony species and antimony associated with soil humic acid molar mass fractions in contaminated soils. Environmental Pollution, 148, 590-598.

Stysz, M., Mączka, M., \& Banduch, R. (2008). The metal ore mining in the area of Bystrzyca Górna, Lubachów and Modliszów - attempt of location and naming of the old excavations on the basis of archival sources and field research. In P. P. Zagożdzon \& M. Madziarz (Eds.), History of mining - the part of European cultural heritage 3 (pp. 459-482). Wrocław: Wydawnictwo Politechniki Wrocławskiej (in Polish, with English abstract).

Stysz, M., Szychowska-Krapiec, E., \& Mączka, M. (2012). The Silberloch adit in the Sowie Mountain according to new archival, cataloguing and dendrochronological research. In P. P. Zagożdzon \& M. Madziarz (Eds.), History of mining the part of European cultural heritage 4 (pp. 351-377). Wrocław: Wydawnictwo Politechniki Wrocławskiej (in Polish, with English abstract).

Sutherland, R. A. (2000). Bed sediment-associated trace metals in an urban stream, Oahu, Hawaii. Environmental Geology, 39, 611-627. 
Szerszeń, L., Chodak, T., \& Karczewska, A. (1993). Areal, profile and time differentiation of heavy metal content in soils in the vicinity of copper smelters in LGOM, Poland. In Eijsackers \& Hamers (Eds.), Integrated soil and sediment research: A basis for proper protection (pp. 79-281). Dordrecht: Kluwer.

Tandy, S., Hockmann, K., Keller, M., Studer, B., Papritz, A., \& Schulin, R. (2018). Antimony mobility during prolonged waterlogging and reoxidation of shooting range soil: a field experiment. The Science of the Total Environment, 624, 838844.

US EPA (2007) Test Method 3051A: microwave assisted acid digestion of sediments, sludges, soils, and oils: https://www. epa.gov/sites/production/files/2015-12/documents/3051a. pdf. Accessed 22 Oct 2018.

van Leeuwen, L. C., Aldenberg, T. (2012). Environmental risk limits for antimony. RIVM Letter Report 601357001/2012. https://rivm.openrepository.com/rivm/bitstream/10029 /259144/3/601357001.pdf. Accessed 09 Oct 2018.

Wang, N., Wang, A., Kong, L., \& He, M. (2018). Calculation and application of $\mathrm{Sb}$ toxicity coefficient for potential ecological risk assessment. The Science of the Total Environment, 610$611,167-174$.
Wei, C., Zhaofeng, G., Chu, W., \& Feng, R. (2015). Speciation of antimony and arsenic in the soils and plants in an old antimony mine. Environmental Experimental Botany, 109, 31-39.

Wenzel, W. W., Kirchbaumer, N., Prochaska, T., Stingeder, G., Lombi, E., \& Adriano, D. C. (2001). Arsenic fractionation in soils using improved sequential extraction procedure. Analytica Chimica Acta, 436, 309-332.

Wilson, N. J., Craw, D., \& Hunter, K. (2004). Antimony distribution and environmental mobility at an historic antimony smelter site, New Zealand. Environmental Pollution, 129, 257-266.

Wilson, S. C., Lockwood, P. V., Ashley, P. M., \& Tighe, M. (2010). The chemistry and behaviour of antimony in the soil environment with comparisons to arsenic: a critical review. Environmental Pollution, 158(5), 1169-1181.

Wilson, S. C., Leech, C. D., Butler, L., Lisle, L., Ashley, P. M., \& Lockwood, P. V. (2013). Effects of nutrient and lime additions in mine site rehabilitation strategies in the accumulation of antimony and arsenic by native Australian plants. Journal of Hazardous Materials, 261, 801-807.

Zagożdżon, M., \& Madziarz, M. (2015). Discovery, opening and preliminary results of investigations of silver mine in Srebrna Góra (former Silberberg; Lower Silesia, Poland). Hereditas minariorum, 2, 179-188. 